\title{
Alternative empiric therapy to carbapenems in management of drug resistant gram negative pathogens: a new way to spare carbapenems
}

Prashant Bhatia

Correspondence: prashantb_34@rediffmail.com

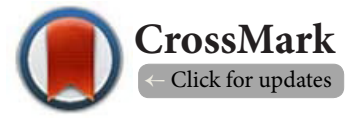

Department of Respiratory Medicine, Asian Institute of Medical Sciences, Faridabad, Haryana, India.

\begin{abstract}
Background: Increasing prevalence of carbapenem resistance in Gram negative bacteria due to excessive and indiscriminate use of carbapenems has forced the medical fraternity to find out ways to spare carbapenems. This retrospective study was aimed to explore a new fixed dose combination (FDC) of ceftriaxone+sulbactam with adjuvant disodium edetate as a carbapenem sparing drug in the management of moderate to severe bacterial infections of lower respiratory tract infections (LRTIs), urinary tract infections (UTIs) and intra-abdominal infections (IAIs).

Methods: A retrospective analysis involves those patients in whom FDC or meropenem was used empirically for the management of these infections caused by multidrug resistant pathogens.

Results: The average age of evaluated patients was $58.17 \pm 13.98$ years. Out of 107 patients, 95 patients selected for the evaluations in which LRTIs, UTIs and IAIs were diagnosed in $43(45.26 \%), 32$ (33.68\%) and $20(21.05 \%)$ patients, respectively. The most common pathogen was Escherichia coli $(38.94 \%)$, followed by Klebsiella species (26.31\%), Pseudomonas species (18.94\%) and Acinetobacter species (15.78\%). According to the susceptibility results, FDC appeared as the most active antibacterial agent against E. coli (94.54\%) followed by Acinetobacter species (93.33\%), Pseudomonas species (88.88\%) and Klebsiella species (84\%). On the other hand, meropenem susceptibility to E. coli was $86.47 \%$ followed by Acinetobacter species $(78.57 \%)$, Pseudomonas species $(66.66 \%)$ and Klebsiella species $(64 \%)$. Further our results revealed that FDC has $>75 \%$ clinical success compared to meropenem ( $61 \%$ clinical success).
\end{abstract}

Conclusion: These results depict non-inferiority of new FDC in the treatment of moderate to severe Gram negative bacterial infections caused by carbapenem resistant organisms and therefore, it should be considered as an alternative to carbapenem for treating LRTIs, UTIs and IAIs.

Keywords: Ceftriaxone/sulbactam-EDTA, lower respiratory tract infections, urinary tract infections, retrospective study

\section{Introduction}

Hospital acquired or nosocomial infections (HAls) are infections occurring during a stay in hospital that are not present at the time of hospital admission. Lower respiratory tract infections (LRTIs), urinary tract infections (UTIs) and intra-abdominal infections (IAls) are amongst the most prevalent HAls [26,36]. LTRIs are thought to be leading cause of death all over the world (WHO, 2008). UTIs are the most common infections among the women, particularly under 50 years of age [27]. IAls, especially complicated IAIs, represent an important cause of morbidity and are frequently associated with poor prognosis [35]. A wide variety of bacterial pathogens are accounting for such infections including Escherichia coli, Pseudomonas aeruginosa, Proteus mirabilis, Klebsiella pneumoniae, Enterobacter spp., and coagulase-negative Staphylococci [21,27]. Empiric antibiotic therapy is commonly used for the treatment of these infections and is usually presumptive and instituted before knowledge of the etiology of specific disease. Among various classes of drugs, $\beta$-lactams are one of the most frequently prescribed empirical antimicrobial drugs for the treatment of such infections [24]. However, in recent years, rise in resistance to $\beta$-lactam drugs has been noticed because of the extended spectrum 
$\beta$-lactamases (ESBLs) enzymes which hydrolyse most of the $\beta$-lactam antibiotics $[10,22,23]$.

To cater the antibiotic resistance due to extended spectrum beta-lactamases (ESBLs), carbapenem drugs have been introduced in clinical settings. Although, carbapenem drugs play a vital role in the management of the infections caused by ESBLs producing organisms due to their broad spectrum activity and stability to hydrolysis against ESBLs [31], carbapenem resistance among the members of the Enterobacteriaceae, Pseudomonas and Acinetobacter has been reported globally $[11,15,22,30]$. The common mechanisms of carbapenem resistance are carbapenem hydrolyzing enzymes, changes in outer membrane proteins, over expression of efflux pumps [32]. Carbapenem resistant organisms are associated with high mortality and morbidity rates and have the potential to spread widely [37]. Increasing use of carbapenem drugs has also a direct alliance with carbapenem resistant Gram negative bacteria [18]. Until recently, most of the older antibiotics have become less useful due to the spread of such carbapenem resistant bacteria. As a result of the increasing resistance towards antibiotics over the past few years, it is no wonder that we are now facing the prospect of losing the battle against many bacterial diseases. Although the new antibiotics have to come along to take their place, the drug development pipeline for new antibiotics has been drying out. The drying antibiotic pipeline particularly against Gram negative bacteria has forced us to look into opportunities for improving usage of the existing antimicrobial agents.

One recently introduced approach to improve the existing antimicrobial agents is the use of antibiotic adjuvant therapy, which potentiates the activity of antibiotics. Adjuvant therapies include antibiotic combinations, synergy between antibiotics and non-antibiotics, inhibition of resistance by altering the physiology of antibiotic-insensitive cells, such as those in biofilms.

Introduction of a novel AAE (antibiotic adjuvant entity) with use of EDTA as adjuvant for chelation and catalytic action to existing antibiotics has been seen as a ray of hope. A new FDC (ceftriaxone, sulbactam with adjuvant EDTA) a novel antibiotic adjuvant entity (AAE) has been reported to have proven efficacy in a wide range of infections $[7,8]$.

This retrospective observational study was aimed to explore a new Fixed Dose Combination (FDC) of Ceftriaxone+Sulbactam with adjuvant Disodium edetate as a carbapenem sparing drug in the management of moderate to severe bacterial infections of LRTIs, UTIs and IAIs.

\section{Methods}

\section{Study design}

This retrospective study was designed to evaluate the efficacy of new FDC in comparison to meropenem in the treatment of the patients who are diagnosed with moderate to severe Gram negative hospital acquired bacterial infections. It was conducted at Asian institute of medical sciences, Faridabad for a period of 18 months between June 2013 to December 2014. All patients admitted to the hospital for more than 48 hours with single pathogen infection and showing sensitivity towards new FDC or Meropenem were considered eligible for the study.

Hospital case sheet files of all the patients were reviewed to collect the necessary data like clinical signs and symptoms at the time of admission of patients and during the course of treatment and finally at the end of therapy. All the necessary lab investigations like sputum, bronchoalveolar lavage (BAL), endotracheal (ET) secretions, urine and blood culture and sensitivity reports, hematology, biochemistry and other relevant investigations carried out at baseline and end of treatment were evaluated from all the enrolled patients.

\section{Bacterial identification}

Identification of bacteria was carried out according to the methods described by Cheesbrough (2000).

\section{Demographic analysis and antibiotic therapy}

The detailed demographic and baseline characteristics of all patients including number of evaluable patients, age, types of infections who were analyzed in this study are given in Table 1. The patients were assigned to receive either meropenem $(1.0 \mathrm{~g}$, every $8 \mathrm{~h}$ ) or new Elores, (ceftriaxone+sulbactam with adjuvant EDTA, $1.5 \mathrm{~g}$ or $3.0 \mathrm{~g}$, every $12 \mathrm{~h}$ ) through intravenous administration. For those patients who were more severe or failed to respond to FDC, colistin with a loading dose of $9 \mathrm{MIU}$ followed by BD doses of $4.5 \mathrm{MIU}$ were used along with previous antibiotic.

The antibiotic therapy of both of the drugs (FDC or meropenem) was initially started empirically based on the clinical symptoms and treating physicians decision and was continued or shifted to other therapy based on the in vitro microbiological susceptibility tests and clinical outcomes. Based on the in vitro antibiotic susceptibility, all the patients were divided into 3 groups for ease of evaluations:

Group-I (G1): Patients with meropenem intermediate and FDC susceptible culture in whom FDC was used ( $n=20,21.05 \%)$. Group-2 (G2): Patients with meropenem and FDC susceptible culture ( $n=65,68.42 \%)$.

Table 1. Demographics characteristics of the patients treated during the study period.

\begin{tabular}{ll}
\hline Characteristic & Value \\
\hline Evaluable patients & 95 \\
Age, mean year SD & $58.17 \pm 13.98$ \\
\hline Type of infection (\%) & $32(33.68 \%)$ \\
\hline UTI & $43(45.26 \%)$ \\
LRTI & $20(21.05 \%)$ \\
IAIs & $62(65.26 \%)$ \\
Number of Infections with Enterobacteriaceae & \\
family pathogens & \\
$\begin{array}{l}\text { Number of Infections with non-Enterobacteriaceae } \\
\text { family pathogens }\end{array}$ & $33(34.73 \%)$ \\
\hline
\end{tabular}


Group-2A (G2A): Patients with meropenem and FDC susceptible culture in whom Meropenem used empirically $(n=31,32.63 \%)$. Group-2B (G2B): Patients with meropenem and FDC susceptible culture in whom FDC used empirically $(n=34,35.78 \%)$. Group-3 (G3): Patients with meropenem and FDC intermediate culture in whom FDC was used empirically along with colistin $(n=10,10.52 \%)$.

\section{In-vitro antibiotic susceptibility testing}

All isolates, recovered from all cultures were subjected to susceptibility testing for FDC, meropenem and colistin using the disk diffusion method according to the recommendations of CLSI (2013). The discs of meropenem $(10 \mu \mathrm{g})$, FDC $(45 \mu \mathrm{g})$ and colistin $(10 \mu \mathrm{g})$ were obtained from Himedia (Mumbai, India). The zones of inhibition surrounding the various antibiotic discs were measured and compared with CLSI. Sensitivity of isolated organisms against antibiotics were reported as sensitive (S) and intermediate (I) based on the breakpoints.

\section{Clinical evaluation of patients}

The clinical efficacy of the therapy was evaluated and classified as cured (resolution of clinical signs and symptoms or improvement not requiring further antibacterial therapy), or failure (persistence of clinical signs and symptoms or worsening in signs and symptoms that required alternative antimicrobial therapy after $72 \mathrm{~h}$ of treatment). The overall efficacy rate was defined as the proportion of the patients cured. Bacterial efficacy was evaluated based on the following four categories: complete eradication if elimination of the original causative pathogens, persistence if the original causative pathogens were repeatedly isolated, substitution if new organisms were isolated on repeated culture and re-infection if re-appearance of the original causative pathogens after eradication and with clinical symptoms of infection.

\section{Results}

Study design and demographic analysis

A total of 107 patients data were evaluated retrospectively in this study. Variables of each patient such as age, causative agents, dosage and regime of antibiotic therapy were recorded. Out of these 107 patients, 95 patients with single bacterial infection were treated either FDC or meropenem. Twelve patients who were either culture negative or treatment failure or expired during course of study were excluded from the study. The average age of patients was $58.17 \pm 13.98$ years.

\section{In vitro antibiotic susceptibility}

On evaluation of culture and sensitivity data, it was observed that clinical samples of the patients were cultured on an appropriate medium, and significant growth was found in 95 samples (88.78\%) which yielded clinically significant pathogen that could be implied as a causative agent. Among bacterial infections, the most common pathogen that was isolated was E. coli which was isolated from 37 patients (38.94\%), followed by Klebsiella spp. ( $\mathrm{n}=25$ patients, $26.31 \%)$, Pseudomonas spp. ( $\mathrm{n}=18$ patients, $18.94 \%$ ) and Acinetobacter spp. (15 patients, $15.78 \%)$. Overall, 62 (65.26\%) pathogens caused infections belonging to the Enterobacteriaceae family while 33 (34.73\%) pathogens belonging to non-Enterobacteriaceae family.

The results of in vitro antimicrobial susceptibility test of FDC and meropenem are presented in Table 2. All the pathogens showed different susceptibility patterns towards FDC and meropenem. According to the susceptibility results, FDC appeared as the most active antibacterial agents against E. coli (94.54\%) followed by Acinetobacter spp. (93.33\%), Pseudomonas spp. (88.88\%) and Klebsiella spp. (84\%). On the other hand, high rates of susceptibility to meropenem were demonstrated by E. coli ( $86.47 \%)$ followed by Acinetobacter spp. (78.57\%), Pseudomonas spp. (66.66\%) and Klebsiella spp. (64\%). Overall, out of 95 pathogens, majority of pathogens $(\mathrm{n}=85,89.47 \%)$ were susceptible to FDC and the remaining 10 pathogens (10.52\%) showed intermediate response to it.

Antibiotics treatment and their efficacy evaluation On day 3 of treatment, progress of the therapy was measured in terms of improvement in the clinical signs and symptoms and microbiological results. Patient with susceptible pathogens with clinical improvement were continued on respective empirical therapies. Patients who were not showing response towards FDC, colistin was given as an add on therapy.

In $\mathrm{G} 1$, out of 20 patients which received FDC, 15 patients (75\%) were clinically cured with complete bacteriological eradication within 7-8 days whereas 5 patients who failed to respond to FDC on day 3 were shifted to FDC+colistin combination therapy and all these patients got cured in additional 8 days therapy making a total of 11 days. The duration of antibiotic treatment in these 15 patients treated with FDC was 7.2 \pm 1.01 days (Table 3). In G2, among 65 patients whose pathogens were susceptible to both FDC and meropenem, 31 patients received meropenem (G2A) and 34 received FDC (G2B). The clinical assessment of meropenem receiving group (G2A) showed cure in 19 patients (61.29\%) while 12 patients (38.70\%) did not show any clinical improvement therefore colistin was added to ongoing therapy. On day 3 ,

Table 2. In-vitro antibiotic susceptibility testing for bacteria isolated from single organism infections.

\begin{tabular}{|c|c|c|c|c|c|}
\hline \multirow{3}{*}{$\begin{array}{l}\text { Isolated } \\
\text { pathogens }\end{array}$} & \multirow{3}{*}{$\begin{array}{l}\text { Number of } \\
\text { individual } \\
\text { isolates }\end{array}$} & \multicolumn{4}{|c|}{ Susceptibility \% } \\
\hline & & \multicolumn{2}{|c|}{$\begin{array}{l}\text { FDC of Ceftriaxone+ } \\
\text { Sulbactam+Disodium } \\
\text { edetate }\end{array}$} & \multicolumn{2}{|c|}{ Meropenem } \\
\hline & & $S$ & I & $\mathbf{S}$ & I \\
\hline E. coli & 37 & 94.54 & 5.4 & 86.47 & 23.53 \\
\hline Klebsiella sp. & 25 & 84 & 16 & 64 & 36 \\
\hline Pseudomonas sp. & 18 & 88.88 & 11.11 & 66.66 & 33.34 \\
\hline Acinetobacter sp. & 15 & 93.33 & 6.66 & 78.57 & 21.43 \\
\hline Total & 95 & -- & -- & -- & -- \\
\hline
\end{tabular}


Table 3. Summary of antibiotic therapy for the group G1 patients with cultures with intermediate resistance to meropenem and susceptible to FDC.

\begin{tabular}{|c|c|c|c|c|c|c|c|c|}
\hline S. No & Age & Organism & FDC dose & $\begin{array}{l}\text { Duration } \\
\text { (days) }\end{array}$ & $\begin{array}{l}\text { Clinical } \\
\text { response }\end{array}$ & Colistin add on & $\begin{array}{l}\text { Duration } \\
\text { (days) }\end{array}$ & $\begin{array}{l}\text { Clinical } \\
\text { response }\end{array}$ \\
\hline 1 & 46 & E. coli & $1.5 \mathrm{~g} \mathrm{BID}$ & 6 & Cured & NA & NA & NA \\
\hline 2 & 55 & E. coli & $3.0 \mathrm{~g} \mathrm{BID}$ & 7 & Cured & NA & NA & NA \\
\hline 3 & 71 & Klebsiella sp. & $3.0 \mathrm{~g} \mathrm{BID}$ & 8 & Cured & NA & NA & NA \\
\hline 4 & 68 & Klebsiella sp. & $1.5 \mathrm{~g} \mathrm{BID}$ & 3 & Deteriorated & $\begin{array}{l}\text { Colistin ( } 9 \text { MIU loading and } \\
4.5 \text { MIU BID) }\end{array}$ & 6 & Cured \\
\hline 5 & 49 & E. coli & $1.5 \mathrm{~g}$ BID & 7 & Cured & NA & NA & NA \\
\hline 6 & 71 & Pseudomonas sp. & $3.0 \mathrm{~g} \mathrm{BID}$ & 7 & Cured & NA & NA & NA \\
\hline 7 & 63 & E. coli & $1.5 \mathrm{~g} \mathrm{BID}$ & 7 & Cured & NA & NA & NA \\
\hline 8 & 52 & Pseudomonas sp. & $3.0 \mathrm{~g} \mathrm{BID}$ & 8 & Cured & NA & NA & NA \\
\hline 9 & 54 & Pseudomonas sp. & $3.0 \mathrm{~g} \mathrm{BID}$ & 8 & Cured & NA & NA & NA \\
\hline 10 & 59 & Klebsiella sp. & $3.0 \mathrm{~g} \mathrm{BID}$ & 9 & Cured & NA & NA & NA \\
\hline 11 & 62 & E. coli & $1.5 \mathrm{~g}$ BID & 5 & Cured & NA & NA & NA \\
\hline 12 & 81 & Klebsiella sp. & $1.5 \mathrm{~g} \mathrm{BID}$ & 8 & Cured & NA & NA & NA \\
\hline 13 & 72 & Pseudomonas sp. & $1.5 \mathrm{~g} \mathrm{BID}$ & 3 & Deteriorated & $\begin{array}{l}\text { Colistin ( } 9 \text { MIU loading and } \\
4.5 \text { MIU BID) }\end{array}$ & 8 & Cured \\
\hline 14 & 66 & Acinetobacter sp. & $3.0 \mathrm{~g} \mathrm{BID}$ & 7 & Cured & NA & NA & NA \\
\hline 15 & 50 & E. coli & $1.5 \mathrm{~g}$ BID & 3 & Deteriorated & $\begin{array}{l}\text { Colistin ( } 9 \text { MIU loading and } \\
4.5 \text { MIU BID) }\end{array}$ & 8 & Cured \\
\hline 16 & 41 & Klebsiella sp. & $3.0 \mathrm{~g}$ BID & 8 & Cured & NA & NA & NA \\
\hline 17 & 76 & Pseudomonas sp. & $1.5 \mathrm{~g}$ BID & 7 & Cured & NA & NA & NA \\
\hline 18 & 39 & E. coli & $3.0 \mathrm{~g} \mathrm{BID}$ & 6 & Cured & NA & NA & NA \\
\hline 19 & 54 & Acinetobacter sp. & $1.5 \mathrm{~g}$ BID & 2 & Deteriorated & $\begin{array}{l}\text { Colistin ( } 9 \text { MIU loading and } \\
4.5 \text { MIU BID) }\end{array}$ & 7 & Cured \\
\hline 20 & 70 & E. coli & $1.5 \mathrm{~g}$ BID & 3 & Deteriorated & $\begin{array}{l}\text { Colistin ( } 9 \text { MIU loading and } \\
4.5 \text { MIU BID) }\end{array}$ & 8 & Cured \\
\hline
\end{tabular}

Note: NA: Not applicable

of these 12 patients, 7 patients (58.33\%) were cured whereas $5(41.66 \%)$ patients failed to respond and were shifted to combination therapy of FDC+colistin and all the patients achieved clinical success. The average duration of treatment was $8.58 \pm 0.96$ days (Table 4). For 34 patients who received FDC, 26 patients $(76.47 \%)$ showed satisfactory clinical cure while in 8 patients (23.52\%) who did not show clinical response at 3 day, colistin was added to the treatment regime that resulted in clinical cure of all patients after additional 7 days. The mean treatment for these 26 cured patients was $8.58 \pm 0.9$ days. The average treatment duration was $7.46 \pm 1.24$ days for patients in the FDC treated group (Table 5).

Among those patients who did not respond to either meropenem or FDC, colistin was added to ongoing therapy and complete clinical success was observed treatment duration $8.67 \pm 0.71$ days (Table 6 and Figure 1).

\section{Discussion}

Carbapenems are $\beta$-lactam antimicrobial agents that are relatively resistant to hydrolysis by most $\beta$-lactamases including
Amp-C and have been considered as the last resort drugs all over the world for the management of serious infections $[1,39]$. However, increasing carbapenem resistance among Gram negative bacteria has been documented greatly in recent years $[16,17,22]$. Amongst various mechanism of carbapenem resistance, acquired metallo- $\beta$-lactamases (MBL) have recently emerged as one of the most worrisome resistance mechanisms owing to their capacity to hydrolyze all $\beta$-lactams, including carbapenems [13].

To combat such increasing carbapenem resistance, novel beta-lactam and beta lactamase inhibitor combination (BL+BLI) has received much attention as a carbapenem alternative drug in recent past $[\mathbf{9}, \mathbf{1 2}, \mathbf{1 5}, \mathbf{2 0}, \mathbf{3 3}]$. However, only BL+BLI combinations did not exhibit significant activity against some ESBLs and majority of MBL producing Gram negative organisms. Hence a novel antibiotic combination of ceftriaxone+sulbactam with adjuvant disodium edetate (proven for efficacy and safety to treat the patients with infections caused by such organisms has been used in current investigations. In the present study, 95 culture positive patients in ICU with 


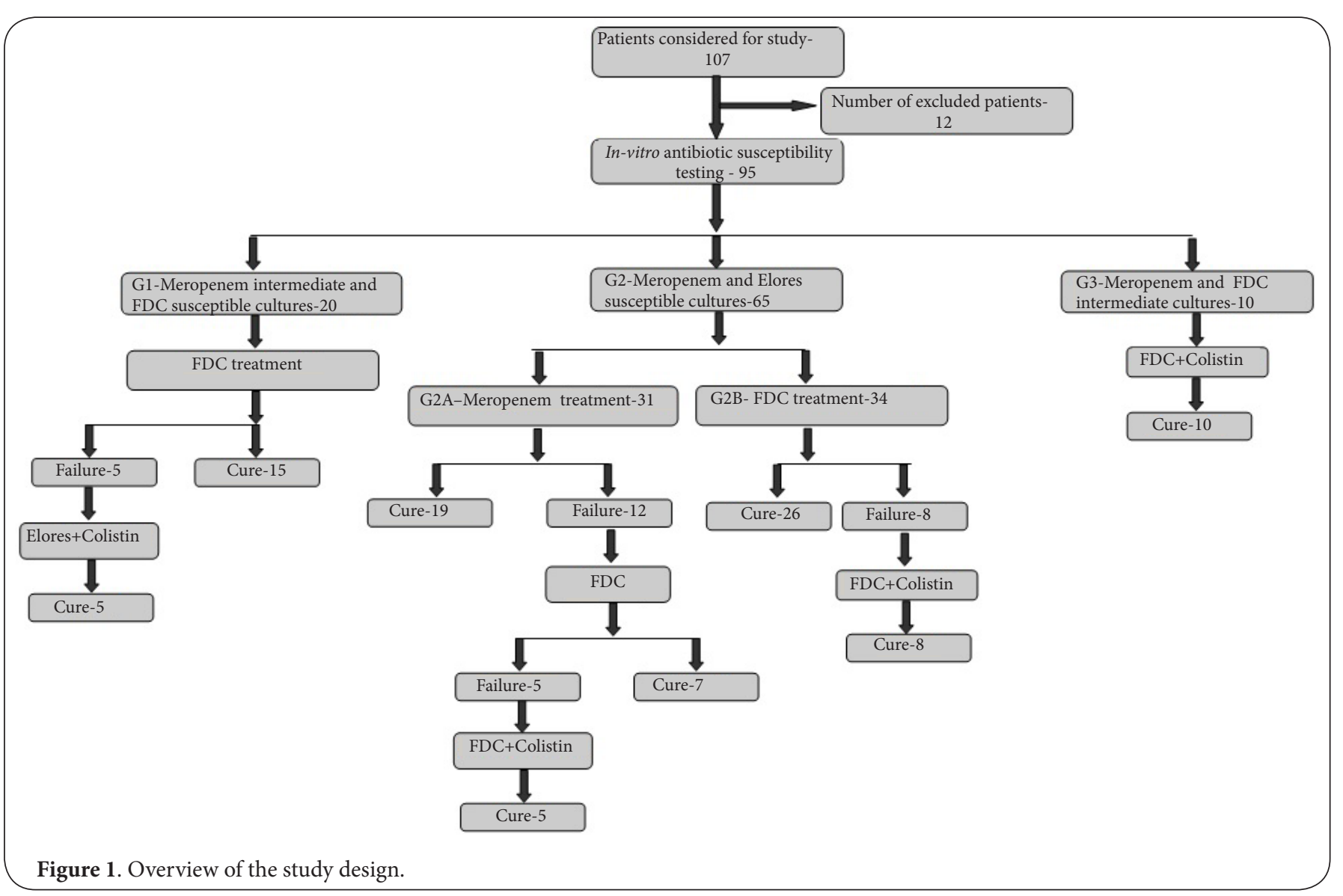

moderate to severe infections treated with this new FDC or meropenem were retrospectively analyzed. The general distribution pattern of nosocomial infections that emerged in our study showed LRTIs (45.26\%) to be the most common, followed by UTIs (33.68\%) and IAls (21.05\%). This is in agreement with the study performed by earlier researcher [14]. The most frequently isolated pathogen was E. coli (38.94\%), followed by Klebsiella spp. (26.31\%), Pseudomonas spp. (18.94\%) and Acinetobacter spp. (15.78\%). This data is in line with many previous studies where E. coli, Klebsiella spp., Pseudomonas spp., and Acinetobacter spp. were reported to be causative agents of LRTIs. UTIs and IAls $[19,29]$.

In the present study, in vitro antimicrobial susceptibility results revealed that $84 \%$ to $91 \%$ of members of Enterobacteriaceae family and 86 to $94 \%$ of non-Enterobacteriaceae family members were sensitive to new FDC. Consistent with these results, earlier reports also demonstrated enhanced activity of this new FDC against members of Enterobacteriaceae and nonEnterobacteriaceae $[4,34]$. On other hands, $64 \%$ to $86 \%$ isolates of Enterobacteriaceae family whereas and $66 \%$ to $78 \%$ members of non-Enterobacteriaceae were susceptible to Meropenem, which is in accordance with previous observations $[4,34]$.

Further, in FDC treated patients an overall success rate was $>75 \%$ against $\sim 61 \%$ in meropenem treated. In G1 $15 / 20$ patients and in G2B 26/34 (75.9\%) who were susceptible to FDC and were administered with FDC achieved clinical and microbiological success suggesting the consistency in in vitro and in vivo results. On the other hand, $5 / 20$ in G1 and 8/34 in G2B (24\%) pathogens who did not respond to FDC in first 3 days were successfully treated when colistin was given with FDC, exploring the new therapeutic options in these failure cases.

In G2A to whom meropenem was given empirically, only 19/31 patients (61.29\%) achieved clinical cure whereas 12 patients failed to respond to meropenem indicating false susceptibility of carbapenem in vitro which is in agreement with previous reports where false susceptibility of carbapenems has been observed in MBL producing strains $[\mathbf{5 , 2 5}]$. Another possibility of the decreased susceptibility of meropenem to members to these isolates implied the presence of outer membrane protein mutation $[\mathbf{2}, \mathbf{2 8}]$. Further when these patients were shifted to Meropenem+Colistin, $5 / 12$ patients $(41.67 \%)$ showed no improvement and were cured when shifted to FDC+Colistin thus indicating presence of MBL strains to which FDC is reported to be active $[4,34]$. This data advocates use of this new FDC as a better alternative to meropenem. Overall, our results indicate the approximately $17 \%$ superiority of new FDC alone over meropenem therapy. It 
Table 4. Summary of antibiotic therapy for the group G2A (Empirical-Meropenem) patients with cultures showing susceptibility to both FDC and meropenem.

\begin{tabular}{|c|c|c|c|c|c|c|c|c|c|c|c|}
\hline $\begin{array}{l}\text { S. } \\
\text { No }\end{array}$ & Age & Organism & $\begin{array}{l}\text { Meropenem } \\
\text { dose }\end{array}$ & $\begin{array}{l}\text { Duration } \\
\text { (days) }\end{array}$ & $\begin{array}{l}\text { Clinical } \\
\text { response }\end{array}$ & Colistin add on & $\begin{array}{l}\text { Duration } \\
\text { (days) }\end{array}$ & $\begin{array}{l}\text { Clinical } \\
\text { response }\end{array}$ & FDC+colistin & $\begin{array}{l}\text { Duration } \\
\text { (days) }\end{array}$ & $\begin{array}{l}\text { Clinical } \\
\text { response }\end{array}$ \\
\hline 1 & 57 & Acinetobacter sp. & $1 \mathrm{~g}$ TID & 8 & Cured & NA & NA & NA & NA & NA & NA \\
\hline 2 & 48 & E. coli & $1 \mathrm{~g}$ TID & 3 & Deteriorated & $\begin{array}{l}\text { Colistin (9 MIU } \\
\text { loading and } 4.5 \\
\text { MIU BID) }\end{array}$ & 6 & Cured & NA & NA & NA \\
\hline 3 & 68 & Pseudomonas sp. & $1 \mathrm{~g}$ TID & 7 & Cured & NA & NA & NA & NA & NA & NA \\
\hline 4 & 61 & Klebsiella sp. & $1 \mathrm{~g}$ TID & 3 & Deteriorated & $\begin{array}{l}\text { Colistin (9 MIU } \\
\text { loading and } 4.5 \\
\text { MIU BID) }\end{array}$ & 2 & Deteriorated & $\begin{array}{l}\text { FDC+Colistin } \\
(9 \mathrm{MIU} \\
\text { loading and } \\
4.5 \text { MIU BID) }\end{array}$ & 6 & Cured \\
\hline 5 & 53 & Klebsiella sp. & $1 \mathrm{~g}$ TID & 9 & Cured & NA & NA & NA & NA & NA & NA \\
\hline 6 & 74 & E. coli & $1 \mathrm{~g}$ TID & 8 & Cured & NA & NA & NA & NA & NA & NA \\
\hline 7 & 55 & E. coli & $1 \mathrm{~g}$ TID & 7 & Cured & NA & NA & NA & NA & NA & NA \\
\hline 8 & 62 & Acinetobacter sp. & $1 \mathrm{~g}$ TID & 3 & Deteriorated & $3.0 \mathrm{~g}$ BID & 7 & Cured & NA & NA & NA \\
\hline 9 & 83 & E. coli & $1 \mathrm{~g}$ TID & 3 & Deteriorated & $3.0 \mathrm{~g}$ BID & 7 & Cured & NA & NA & NA \\
\hline 10 & 40 & Pseudomonas sp. & $1 \mathrm{~g}$ TID & 10 & Cured & NA & NA & NA & NA & NA & NA \\
\hline 11 & 76 & Klebsiella sp. & $1 \mathrm{~g}$ TID & 10 & Cured & NA & NA & NA & NA & NA & NA \\
\hline 12 & 54 & Acinetobacter sp. & $1 \mathrm{~g}$ TID & 8 & Cured & NA & NA & NA & $\mathrm{NA}$ & NA & NA \\
\hline 13 & 68 & Klebsiella sp. & $1 \mathrm{~g}$ TID & 2 & Deteriorated & $\begin{array}{l}\text { Colistin (9 MIU } \\
\text { loading and } 4.5 \\
\text { MIU BID) }\end{array}$ & 2 & Deteriorated & $\begin{array}{l}\text { FDC+Colistin } \\
(9 \mathrm{MIU} \\
\text { loading and } \\
4.5 \mathrm{MIU} \text { BID) }\end{array}$ & 6 & Cured \\
\hline 14 & 39 & E. coli & $1 \mathrm{~g}$ TID & 8 & Cured & NA & NA & NA & $\mathrm{NA}$ & NA & NA \\
\hline 15 & 70 & Pseudomonas sp. & $1 \mathrm{~g}$ TID & 3 & Deteriorated & $\begin{array}{l}\text { Colistin (9 MIU } \\
\text { loading and } 4.5 \\
\text { MIU BID) }\end{array}$ & 2 & Deteriorated & $\begin{array}{l}\text { FDC+Colistin } \\
(9 \mathrm{MIU} \\
\text { loading and } \\
4.5 \mathrm{MIU} \text { BID) }\end{array}$ & 7 & Cured \\
\hline 16 & 42 & Pseudomonas sp. & $1 \mathrm{~g}$ TID & 9 & Cured & NA & NA & NA & NA & NA & NA \\
\hline 17 & 64 & Acinetobacter sp. & $1 \mathrm{~g}$ TID & 9 & Cured & NA & NA & NA & NA & NA & NA \\
\hline 18 & 37 & Acinetobacter sp. & $1 \mathrm{~g}$ TID & 3 & Deteriorated & $\begin{array}{l}\text { Colistin (9 MIU } \\
\text { loading and } 4.5 \\
\text { MIU BID) }\end{array}$ & 8 & Cured & NA & NA & NA \\
\hline 19 & 78 & E. coli & $1 \mathrm{~g}$ TID & 8 & Cured & NA & NA & NA & NA & NA & NA \\
\hline 20 & 66 & Klebsiella sp. & $1 \mathrm{~g}$ TID & 9 & Cured & NA & NA & NA & NA & NA & NA \\
\hline 21 & 59 & Klebsiella sp. & $1 \mathrm{~g}$ TID & 2 & Deteriorated & $\begin{array}{l}\text { Colistin (9 MIU } \\
\text { loading and } 4.5 \\
\text { MIU BID) }\end{array}$ & 8 & Cured & NA & NA & NA \\
\hline 22 & 40 & E. coli & $1 \mathrm{~g}$ TID & 3 & Deteriorated & $\begin{array}{l}\text { Colistin (9 MIU } \\
\text { loading and } 4.5 \\
\text { MIU BID) }\end{array}$ & 2 & Deteriorated & $\begin{array}{l}\text { FDC+Colistin } \\
(9 \mathrm{MIU} \\
\text { loading and } \\
4.5 \mathrm{MIU} \text { BID) }\end{array}$ & 7 & Cured \\
\hline 23 & 59 & Acinetobacter sp. & $1 \mathrm{~g}$ TID & 8 & Cured & NA & NA & NA & NA & NA & NA \\
\hline 24 & 60 & Klebsiella sp. & $1 \mathrm{~g}$ TID & 8 & Cured & NA & NA & NA & NA & NA & NA \\
\hline 25 & 47 & E. coli & $1 \mathrm{~g}$ TID & 2 & Deteriorated & $\begin{array}{l}\text { Colistin (9 MIU } \\
\text { loading and } 4.5 \\
\text { MIU BID) }\end{array}$ & 8 & Cured & NA & NA & NA \\
\hline 26 & 70 & Pseudomonas sp. & $1 \mathrm{~g}$ TID & 10 & Cured & NA & NA & NA & NA & NA & NA \\
\hline 27 & 46 & E. coli & $1 \mathrm{~g}$ TID & 8 & Cured & NA & NA & NA & NA & NA & NA \\
\hline 28 & 51 & Klebsiella sp. & $1 \mathrm{~g}$ TID & 3 & Deteriorated & $\begin{array}{l}\text { Colistin (9 MIU } \\
\text { loading and } 4.5 \\
\text { MIU BID) }\end{array}$ & 9 & Cured & NA & NA & NA \\
\hline 29 & 60 & E. coli & $1 \mathrm{~g}$ TID & 9 & Cured & NA & NA & NA & NA & NA & NA \\
\hline 30 & 72 & Pseudomonas sp. & $1 \mathrm{~g}$ TID & 3 & Deteriorated & $\begin{array}{l}\text { Colistin (9 MIU } \\
\text { loading and } 4.5 \\
\text { MIU BID) }\end{array}$ & 2 & Deteriorated & $\begin{array}{l}\text { FDC+Colistin } \\
(9 \mathrm{MIU} \\
\text { loading and } \\
4.5 \text { MIU BID) }\end{array}$ & 6 & Cured \\
\hline 31 & 48 & E. coli & $1 \mathrm{~g}$ TID & 10 & Cured & NA & NA & NA & NA & NA & NA \\
\hline
\end{tabular}


Table 5. Summary of antibiotic therapy for the group G2B (Empirical-FDC) patients with cultures showing susceptibility to both FDC and meropenem.

\begin{tabular}{|c|c|c|c|c|c|c|c|c|}
\hline S. No & Age & Organism & FDC dose & $\begin{array}{l}\text { Duration } \\
\text { (days) }\end{array}$ & $\begin{array}{l}\text { Clinical } \\
\text { response }\end{array}$ & Colistin add on & $\begin{array}{l}\text { Duration } \\
\text { (days) }\end{array}$ & $\begin{array}{l}\text { Clinical } \\
\text { response }\end{array}$ \\
\hline 1 & 7 & Acinetobacter sp. & $1.5 \mathrm{~g} \mathrm{BID}$ & 7 & Cured & NA & NA & NA \\
\hline 2 & 81 & E. coli & $1.5 \mathrm{~g}$ BID & 6 & Cured & NA & NA & NA \\
\hline 3 & 65 & E. coli & $1.5 \mathrm{~g} \mathrm{BID}$ & 7 & Cured & NA & NA & NA \\
\hline 4 & 80 & Pseudomonas sp. & $3.0 \mathrm{~g} \mathrm{BID}$ & 9 & Cured & NA & NA & NA \\
\hline 5 & 72 & Klebsiella sp. & $1.5 \mathrm{~g}$ BID & 3 & Deteriorated & $\begin{array}{l}\text { Colistin (9 MIU loading and } 4.5 \\
\text { MIUBID) }\end{array}$ & 7 & Cured \\
\hline 6 & 65 & E. coli & $1.5 \mathrm{~g}$ BID & 5 & Cured & NA & NA & NA \\
\hline 7 & 40 & Acinetobacter sp. & $3.0 \mathrm{~g} \mathrm{BID}$ & 6 & Cured & NA & NA & NA \\
\hline 8 & 62 & Klebsiella sp. & $1.5 \mathrm{~g}$ BID & 8 & Cured & NA & NA & NA \\
\hline 9 & 51 & E. coli & $1.5 \mathrm{~g}$ BID & 3 & Deteriorated & $\begin{array}{l}\text { Colistin ( } 9 \text { MIU loading and } 4.5 \text { MIU } \\
\text { BID) }\end{array}$ & 7 & Cured \\
\hline 10 & 39 & E. coli & $1.5 \mathrm{~g}$ BID & 8 & Cured & NA & NA & NA \\
\hline 11 & 35 & Pseudomonas sp. & $3.0 \mathrm{~g} \mathrm{BID}$ & 8 & Cured & NA & NA & NA \\
\hline 12 & 47 & Pseudomonas sp. & $1.5 \mathrm{~g} \mathrm{BID}$ & 9 & Cured & NA & NA & NA \\
\hline 13 & 55 & Klebsiella sp. & $1.5 \mathrm{~g} \mathrm{BID}$ & 3 & Deteriorated & $\begin{array}{l}\text { Colistin ( } 9 \text { MIU loading and } 4.5 \text { MIU } \\
\text { BID) }\end{array}$ & 6 & Cured \\
\hline 14 & 70 & Pseudomonas sp. & $3.0 \mathrm{~g} \mathrm{BID}$ & 9 & Cured & NA & NA & NA \\
\hline 15 & 61 & E. coli & $3.0 \mathrm{~g} \mathrm{BID}$ & 8 & Cured & NA & NA & NA \\
\hline 16 & 45 & E. coli & $1.5 \mathrm{~g} \mathrm{BID}$ & 6 & Cured & NA & NA & NA \\
\hline 17 & 66 & Klebsiella sp. & $1.5 \mathrm{~g} \mathrm{BID}$ & 2 & Deteriorated & $\begin{array}{l}\text { Colistin ( } 9 \text { MIU loading and } 4.5 \text { MIU } \\
\text { BID) }\end{array}$ & 7 & Cured \\
\hline 18 & 76 & E. coli & $1.5 \mathrm{~g} \mathrm{BID}$ & 6 & Cured & NA & NA & NA \\
\hline 19 & 49 & Acinetobacter sp. & $3.0 \mathrm{~g}$ BID & 9 & Cured & NA & NA & NA \\
\hline 20 & 71 & E. coli & $1.5 \mathrm{~g} \mathrm{BID}$ & 3 & Deteriorated & $\begin{array}{l}\text { Colistin (9 MIU loading and } 4.5 \text { MIU } \\
\text { BID) }\end{array}$ & 7 & Cured \\
\hline 21 & 62 & Pseudomonas sp. & $3.0 \mathrm{~g}$ BID & 10 & Cured & NA & NA & NA \\
\hline 22 & 68 & E. coli & $1.5 \mathrm{~g}$ BID & 7 & Cured & NA & NA & NA \\
\hline 23 & 50 & Acinetobacter sp. & $1.5 \mathrm{~g}$ BID & 3 & Deteriorated & $\begin{array}{l}\text { Colistin ( } 9 \text { MIU loading and } 4.5 \text { MIU } \\
\text { BID) }\end{array}$ & 8 & Cured \\
\hline 24 & 53 & E. coli & $1.5 \mathrm{~g} \mathrm{BID}$ & 7 & Cured & NA & NA & NA \\
\hline 25 & 40 & E. coli & $3.0 \mathrm{~g} \mathrm{BID}$ & 7 & Cured & NA & NA & NA \\
\hline 26 & 38 & Klebsiella sp. & $3.0 \mathrm{~g}$ BID & 3 & Deteriorated & $\begin{array}{l}\text { Colistin (9 MIU loading and } 4.5 \text { MIU } \\
\text { BID) }\end{array}$ & 6 & Cured \\
\hline 27 & 72 & Klebsiella sp. & $3.0 \mathrm{~g}$ BID & 8 & Cured & NA & NA & NA \\
\hline 28 & 44 & E. coli & $1.5 \mathrm{~g}$ BID & 7 & Cured & NA & NA & NA \\
\hline 29 & 46 & Pseudomonas sp. & $1.5 \mathrm{~g}$ BID & 3 & Deteriorated & $\begin{array}{l}\text { Colistin (9 MIU loading and } 4.5 \text { MIU } \\
\text { BID) }\end{array}$ & 7 & Cured \\
\hline 30 & 57 & E. coli & $1.5 \mathrm{~g}$ BID & 7 & Cured & NA & NA & NA \\
\hline 31 & 68 & Klebsiella sp. & $3.0 \mathrm{~g}$ BID & 9 & Cured & NA & NA & NA \\
\hline 32 & 75 & E. coli & $1.5 \mathrm{~g} \mathrm{BID}$ & 6 & Cured & NA & NA & NA \\
\hline 33 & 60 & Acinetobacter sp. & $1.5 \mathrm{~g}$ BID & 8 & Cured & NA & NA & NA \\
\hline 34 & 44 & Klebsiella sp. & $3.0 \mathrm{~g} \mathrm{BID}$ & 7 & Cured & NA & NA & NA \\
\hline
\end{tabular}

Note: NA: Not applicable 
Prashant Bhatia, Research Journal of Infectious Diseases 2015,

http://www.hoajonline.com/journals/pdf/2052-5958-3-2.pdf

doi: $10.7243 / 2052-5958-3-2$

Table 6. Summary of antibiotic therapy for the group G3 patients with cultures showing intermediate resistance to FDC and Meropenem.

\begin{tabular}{llllll}
\hline S. No & Age & Organism & FDC+Colistin dose & $\begin{array}{l}\text { Duration } \\
\text { (days) }\end{array}$ & $\begin{array}{l}\text { Clinical } \\
\text { response }\end{array}$ \\
\hline 1 & 79 & E. coli & 3.0 g FDC+Colistin (9 MIU loading and 4.5 MIU BID) & 8 & Cured \\
2 & 41 & Klebsiella sp. & 3.0 g FDC+Colistin (9 MIU loading and 4.5 MIU BID) & 8 & Cured \\
3 & 65 & E. coli & 3.0 g FDC+Colistin (9 MIU loading and 4.5 MIU BID) & 9 & Cured \\
4 & 82 & E. coli & 3.0 g FDC+Colistin (9 MIU loading and 4.5 MIU BID) & 9 & Cured \\
5 & 66 & Klebsiella sp. & 3.0 g FDC+Colistin (9 MIU loading and 4.5 MIU BID) 10 & Cured \\
6 & 74 & Klebsiella sp. & 3.0 g FDC+Colistin (9 MIU loading and 4.5 MIU BID) 9 & Cured \\
7 & 50 & Pseudomonas sp. & 3.0 g FDC+Colistin (9 MIU loading and 4.5 MIU BID) 8 & Cured \\
8 & 43 & Klebsiella sp. & 3.0 g FDC+Colistin (9 MIU loading and 4.5 MIU BID) & 8 & Cured \\
9 & 71 & Acinetobacter sp. & 3.0 g FDC+Colistin (9 MIU loading and 4.5 MIU BID) & 9 & Cured \\
10 & 36 & Acinetobacter sp. & 3.0 g FDC+Colistin (9 MIU loading and 4.5 MIU BID) & 8 & Cured \\
\hline
\end{tabular}

has been noticed that 15 to $20 \%$ mortality rates in patients of nosocomial infections has been associated [14]. However, this percentage was very low in our case. There was no significant difference in treatment regimen of two therapies however, dosing frequency and cost of drug was lower in FDC treated group as compared to meropenem treated.

\section{Conclusion}

Our data showed that FDC can be a good option as carbapenem sparing drug and combination of FDC and colistin can successfully treat complicated multi drug resistant cases of LRTIs, UTIs, and IAls without mortality within 8-11 days.

\section{Competing interests}

The author declares that he has no competing interests.

\section{Acknowledgement}

The author would like to thank all patients, paramedical staff, critical care and microbiology teams for assisting in collection of data and preparation of the manuscript.

Publication history

EIC: Ishtiaq Qadri, King Abdul Aziz University, Saudi Arabia. Received: 10-Jun-2015 Final Revised: 11-Jul-2015 Accepted: 13-Jul-2015 Published: 20-Jul-2015

\section{References}

1. Amjad A, Mirza I, Abbasi S, Farwa U, Malik N and Zia F. Modified Hodge test: A simple and effective test for detection of carbapenemase production. Iran J Microbiol. 2011; 3:189-93. | PubMed Abstract | PubMed Full Text

2. Bradford PA, Urban C, Mariano N, Projan SJ, Rahal JJ and Bush K. Imipenem resistance in Klebsiella pneumoniae is associated with the combination of ACT-1, a plasmid-mediated AmpC beta-lactamase, and the foss of an outer membrane protein. Antimicrob Agents Chemother. 1997; 41:563-9. | Article | PubMed Abstract | PubMed Full Text

3. Cheesbrough M. Biochemical tests to identify bacteria. In: District laboratory practice in tropical countries. 2nd edition. Cambridge University Press, UK. 2000; 178-187.

4. Chaudhary $M$, Kumar S and Payasi A. Prevalence and antimicrobial sensitivity of extended spectrum beta-lactamase producing Gram negative bacteria from clinical settings in India from 2010-2012. Int J Med Med Sci. 2013; 46:1212-1217. I Pdf

5. Chaudhary $M$ and Payasi $A$. False susceptibility of antibitoics to carbapenemase producers and means to overcome. IOSR J Phar Biol Sci. 2014; 9:155-161.

6.Clinical Laboratory Standard Institute. Performance Standards for Antimicrobial Susceptibility Testing; Twenty-Second Informational Supplement. Clinical Laboratory Standard Institute. Wayne, Pennsylvania, USA. 2013; 32.

7. Chaudhary $M$ and Payasi A. A randomidez, open label prospective, multicenter phase-III clinical trial of Elores in lower respiratory tract and urinary tract infections. J. Pharmacy Res. 2013; 6:409-414. | Article

8. Chaudhary $M$ and Payasi A. Clinical, microbial efficacy and tolerability of Elores, a novel antibiotic adjuvant entity in ESBL producing pathogens: Prospective randomized controlled clinical trial. J Pharmacy Res. 2013; 6:275-280. | Article

9. Chakraborty D, Basu S and Das S. A study on infections caused by metallo-betalactamase producing Gram-negative bacteria in intensive care unit patients. Am J Infect Dis. 2010; 6:34-9. | Pdf

10. Cornaglia $\mathrm{G}$ and Rossolini GM. The emerging threat of acquired carbapenemases in Gram-negative bacteria. Clin Microbiol Infect. 2010; 16:99-101. | Article | PubMed

11. Chitnis AS, Caruthers PS, Rao AK, Lamb J, Lurvey R, Beau De Rochars V, Kitchel B, Cancio M, Torok TJ, Guh AY, Gould CV and Wise ME. Outbreak of carbapenem-resistant enterobacteriaceae at a long-term acute care hospital: sustained reductions in transmission through active surveillance and targeted interventions. Infect Control Hosp Epidemiol. 2012; 33:984-92. I Article I PubMed

12. Datta S, Wattal C, Goel N, Oberoi JK, Raveendran R and Prasad KJ. A ten year analysis of multi-drug resistant blood stream infections caused by Escherichia coli \& Klebsiella pneumoniae in a tertiary care hospital. Indian J Med Res. 2012; 135:907-12. | Article | PubMed Abstract | PubMed Full Text

13. Deshmukh DG, Damle AS, Bajaj JK, Bhakre JB and Patwardhan NS. Metallo-beta-lactamase-producing clinical isolates from patients of a tertiary care hospital. J Lab Physicians. 2011; 3:93-7. | Article | PubMed Abstract I PubMed Full Text

14. Ding JG, Sun QF, Li KC, Zheng MH, Miao XH, Ni W, Hong L, Yang JX, Ruan ZW, Zhou RW, Zhou HJ and He WF. Retrospective analysis of nosocomial infections in the intensive care unit of a tertiary hospital in China during 2003 and 2007. BMC Infect Dis. 2009; 9:115. | Article | PubMed Abstract | PubMed Full Text

15. Deshpande P, Rodrigues C, Shetty A, Kapadia F, Hedge A and Soman R. New Delhi Metallo-beta lactamase (NDM-1) in Enterobacteriaceae: 
treatment options with carbapenems compromised. J Assoc Physicians India. 2010; 58:147-9. | PubMed

16. Francis RO, Wu F, Della-Latta P, Shi J and Whittier S. Rapid detection of Klebsiella pneumoniae carbapenemase genes in enterobacteriaceae directly from blood culture bottles by real-time PCR. Am J Clin Pathol. 2012; 137:627-32. | Article | PubMed

17. Grundmann H, Livermore DM, Giske CG, Canton R, Rossolini GM, Campos J, Vatopoulos A, Gniadkowski M, Toth A, Pfeifer Y, Jarlier V and Carmeli Y. Carbapenem-non-susceptible Enterobacteriaceae in Europe: conclusions from a meeting of national experts. Euro Surveill. 2010; 15:46. | Article | PubMed

18. Goel N, Wattal C, Oberoi JK, Raveendran R, Datta S and Prasad KJ. Trend analysis of antimicrobial consumption and development of resistance in non-fermenters in a tertiary care hospital in Delhi, India. J Antimicrob Chemother. 2011; 66:1625-30. | Article | PubMed

19. Haddad M. Antimicrobial resistance of uropathogens and rationale for empirical therapy in Jordan. Biomed Biopharmacol J. 2014; 7:1-8. | Pdf

20. Hodiwala A, Dhoke R and Urhekar AD. Incidence of metallo-betalactamase producing Pseudomonas, Acinetobacter \& Enterobacterial isolates in hospitalised patients. Int J Pharam Biol Sci. 2013; 3:79-83. | Pdf

21. Horvath DJ, Jr., Dabdoub SM, Li B, Vanderbrink BA and Justice SS. New paradigms of urinary tract infections: Implications for patient management. Indian J Urol. 2012; 28:154-8. | Article | PubMed Abstract I PubMed Full Text

22. Hu F, Chen S, Xu X, Guo Y, Liu Y, Zhu D and Zhang Y. Emergence of carbapenem-resistant clinical Enterobacteriaceae isolates from a teaching hospital in Shanghai, China. J Med Microbiol. 2012; 61:132-6. | Article | PubMed

23. Jalalpour $S$ and Ebadi AG. Role of nano structure of crystalline layer and beta- lactamase nano enzyme in antibiotics resistant bacteria. Afr J Pharm Pharmacol. 2012; 6:113-118. | Pdf

24. Khajuria A, Praharaj AK, Kumar M and Grover N. Carbapenem Resistance among Enterobacter Species in a Tertiary Care Hospital in Central India. Chemother Res Pract. 2014; 2014:972646. | Article | PubMed Abstract | PubMed Full Text

25. Lee K, Lim YS, Yong D, Yum JH and Chong Y. Evaluation of the Hodge test and the imipenem-EDTA double-disk synergy test for differentiating metallo-beta-lactamase-producing isolates of Pseudomonas spp. and Acinetobacter spp. J Clin Microbiol. 2003; 41:4623-9. | Article | PubMed Abstract | PubMed Full Text

26. Magill SS, Edwards JR, Bamberg W, Beldavs ZG, Dumyati G, Kainer MA, Lynfield R, Maloney M, McAllister-Hollod L, Nadle J, Ray SM, Thompson DL, Wilson LE and Fridkin SK. Multistate point-prevalence survey of health care-associated infections. N Engl J Med. 2014; 370:1198-208. | Article I PubMed

27. Minardi D, d'Anzeo G, Cantoro D, Conti A and Muzzonigro G. Urinary tract infections in women: etiology and treatment options. Int J Gen Med. 2011; 4:333-43. | Article | PubMed Abstract | PubMed Full Text

28. Modakkas EM and Sanyal SC. Imipenem resistance in aerobic gramnegative bacteria. J Chemother. 1998; 10:97-101. | Article | PubMed

29. Okesola AO and Ige OM. Trends in bacterial pathogens of lower respiratory tract infections. Indian J Chest Dis Allied Sci. 2008; 50:269-72. I Pdf I PubMed

30. Perez F and Van Duin D. Carbapenem-resistant Enterobacteriaceae: a menace to our most vulnerable patients. Cleve Clin J Med. 2013; 80:22533. | Article | PubMed Abstract | PubMed Full Text

31. Pravin KN and Michelle SV. Prevalence of carbapenem resistant Enterobacteriaceae from a tertiary care hospital in Mumbai, India. J Microbiol Infect Dis. 2013; 3:207-210. | Pdf

32. Rodrigues C. Carbapenem-resistant enterobacteriaceae: a reality check. Reg Health Forum. 2011; 15:83-86. I Pdf

33. Rodriguez-Bano J, Navarro MD, Retamar P, Picon E and Pascual A. beta-Lactam/beta-lactam inhibitor combinations for the treatment of bacteremia due to extended-spectrum beta-lactamase-producing Escherichia coli: a post hoc analysis of prospective cohorts. Clin Infect Dis. 2012; 54:167-74. | Article | PubMed
34. Sahu M, Sanjith S, Bhalekar P and Keny D. Waging war against extended spectrum Beta lactamase and metallobetalactamase producing pathogens- novel adjuvant antimicrobial agent cse1034- an extended hope. J Clin Diagn Res. 2014; 8:DC20-3. | Article | PubMed Abstract | PubMed Full Text

35. Sartelli M. A focus on intra-abdominal infections. World J Emerg Surg. 2010; 5:9. | Article | PubMed Abstract | PubMed Full Text

36. Solomkin JS, Mazuski JE, Bradley JS, Rodvold KA, Goldstein EJ, Baron EJ, O'Neill PJ, Chow AW, Dellinger EP, Eachempati SR, Gorbach S, Hilfiker M, May AK, Nathens AB, Sawyer RG and Bartlett JG. Diagnosis and management of complicated intra-abdominal infection in adults and children: guidelines by the Surgical Infection Society and the Infectious Diseases Society of America. Clin Infect Dis. 2010; 50:133-64. | Article | PubMed

37. Toolkit CRE. CDC-Guidance for Control of Carbapenem-resistant Enterobacteriaceae (CRE). 2012. | Pdf

38. World Health Organization. The 10 leading causes of death by broad income group. 2008. | Pdf

39. Zavascki AP, Carvalhaes CG, Picao RC and Gales AC. Multidrug-resistant Pseudomonas aeruginosa and Acinetobacter baumannii: resistance mechanisms and implications for therapy. Expert Rev Anti Infect Ther. 2010; 8:71-93. | Article | PubMed

\section{Citation:}

Bhatia P. Alternative empiric therapy to carbapenems in management of drug resistant gram negative pathogens: a new way to spare carbapenems. Res J Infect Dis. 2015; 3:2.

http://dx.doi.org/10.7243/2052-5958-3-2 